\title{
PART 8. \\ THEORETICAL AND METHODOLOGICAL FRAMEWORK FOR THE STUDY OF THE EASTERN ENLARGEMENT OF THE EUROPEAN UNION
}

Theoretical and methodological framework for the study is based on interdisciplinary approach which provides the opportunity to analyse every element of the European integration process of Central European countries comprehensively, taking into account the impact of economic, institutional and political factors. The application of the systems approach, which is the basis of this scientific study, has facilitated clear formulation of the existing problems and finding logical ways of solving them.

With that being said, an important component of the search for European integration theories, which would adequately explain current European integration processes or outline the clear directions for the future development of the EU's eastern enlargement, or the actual development of the Central European region, is an awareness of the existence of multivariate interpretations of the role and significance of the subjects of international relations. "Europe will not be made all at once, or according to a single plan. It will be built through concrete achievements which first create a de facto solidarity" - Robert Schuman ${ }^{412}$. The aforementioned thesis, that is, in fact, the first principle of the Schuman Declaration, clearly and logically explains the very essence of the European integration process, and moreover, in the theoretical dimension as well. First of all, it proves the incapacity of the federalist approach in the initial phase of the development of European integration - as the inability to create a federal superpower, despite the existence of successful models of the federal system in the world. Secondly, this principle reflects the essence of the philosophy of development of European integration, namely the precedence of practice, and not the formation of a priori ideologemes or theoretical constructs, which should be followed by practice. Essentially, conceptually the theories of integration did not act and did not serve as determinants of political decisions neither at the beginning of the creation of European integration, nor today.

${ }^{1}$ A new idea for Europe. The Schuman declaration - 1950-2000. European Commission. Series: European Documentation. - Luxembourg: Office for Official Publications of the European Communities, 2000. -15 p. 
Thirdly, the subject of research in the theory of European integration itself - the evolution, elements and mechanisms of action of the European Union - indicates the existence of different scientific opinions. Primarily, these interpretations concern the qualitative definition of the EU along with other international, or rather intergovernmental, organizations of the world as primus inter pares. From other perspectives European integration is considered as one of the segments of regional integration of the world, or vice versa, is distinguished to be a unique European integration process on a global scale.

However, it should be noted that there is no unanimous opinion on the fundamental questions of the political theory of European integration, and it is hardly possible that there could be one. It is completely clear that the economic theory of European integration has been thoroughly elaborated. According to the key points of integration theory, initially European integration used to be seen as some union such as the USA or faced radical objections with opinions why this path would be not acceptable for Europe.

From the existing array of theoretical generalizations in the context of both deepening and widening of the European Union, first of all, three basic conceptual generalizations should be distinguished, which can also characterize the essence of the European integration progress of the countries of Central Europe.

The first one is "multi-speed" Europe (the term first appeared in the Tindemans Report (1975) which describes a situation where not all member states are able to, or want to, move towards integration in a particular field at the same pace. However, certain measures aimed at reconciling the interests of different groups of states become necessary. In general, the provisions of the Tindemans Report were rejected, but the introduction of the European exchange rate mechanism (in the late 1970s) allowed for the possibility of "different speeds" within the European monetary system. Real threats to the emergence of multi-speed Europe today also emerged after the first unsuccessful attempt at adopting the EU Constitution, which also indicated the possible crisis in the context of creating a single entity in international relations.

The second one is Europe a la carte - the so-called "menu" of development strategies for European countries - that is a model of European integration, by which states choose whether or not to participate in a particular integration initiative. Such a model was followed, for example, by the British Government, using the so-called opt-out on the provisions of the "Social Package" of the Maastricht Agreement. This term reflects the idea of a variety of different methods of integration that allows member states to choose strategies "from the menu" and engage in their implementation. The given model may pose a threat to the entire process of European integration, 
so there should be at least a minimum number of common goals for the member states of the EU (by the way, another name for this model of European integration is the "variable geometry" Europe).

The third one is Europe of concentric circles - the concept of European integration proposed by Jacques Delors in January 1989, which envisages an increasing level of integration towards the "center" of the European Community which comprises of the EU countries that have already created a political union, common market and economic and monetary union. Next would be the countries of the European Free Trade Association, which are closer to the EU in economic and legal terms. The outer circle would be made up of associated countries that are eligible to apply for the EU membership in the future. The fourth and the widest circle includes the OSCE member states as a common space for European cooperation ${ }^{413}$.

The analysis of theoretical models of integration processes, particularly of European integration, provides an opportunity to investigate the dynamics of the integration process itself. This issue is studied by international law, world economy, international relations, political science etc. In Ukraine this is mainly studied as international integration. Today, Ukrainian scientists are meticulously characterizing the existing integration models of the European Union, which in turn forms the home school of "European studies". However, the study of theoretical models of integration, as well as the theory and practice of European integration in general, and in the region of Central Europe in particular, requires deep rethinking on the basis of a critical analysis of existing developments and an examination of the correspondence of theoretical foundations to the dynamic development of the modern European integration process.

An issue of current importance for the theory and practice of European integration today is the development of a modern theory of the European integration process, its imaginary or real components, as the ability to understand each of today's, and most importantly, the "tomorrow's" steps of the EU. It is necessary not only for the EU but even more so for the Central European countries and is extremely important for Ukraine. The future of Ukraine should not be limited by the Copenhagen Criteria or any other documents, as these issues are complex but still technical, and we see the solution to the problem in the strategic planning of the European integration policy of the country under the conditions of a conceptually thought out theory of the European integration process.

The scientific importance of the problem lies in the fact that today, in the context of continuous dynamic development, which is, in fact, a radical

\footnotetext{
${ }^{2}$ Європейський Союз. Словник-довідник. - К.: К.І.С., 2001 - С. 25-26.
} 
transformation of the European Union, it is essential to develop new models of the European integration process, at least of the theory of EU enlargement. It should be noted that some attempts to do this have already been made in the Western scientific literature ${ }^{414}$, there are even studies that attempt to "calculate" the benefits and losses of the EU's eastern enlargement ${ }^{415}$, but in fact, the problem is that these theoretical models do not stand the test of time - that is, the theory cannot "catch up" with the flow of time. The inability to develop an effective Eastern policy today for such a respectable international association, and in fact, a real subject of international relations as the European Union, indicates the lack of conceptual theoretical and methodological generalizations about the "newest eastern periphery of the European Union". Practically, the theory does not keep up with the practice of learning by trial and error currently used by the EU for its eastern policy.

And, in fact, current theoretical generalizations do not meet the challenges of the present-day EU enlargement. Let's just mention the absence of a clear EU strategy for eastern enlargement, which resulted in Central European countries reaping the "benefits" of it even now, being full members of the EU. Whether it would be unsuccessful but "always relevant" quasi-discussions about the recent borders of Europe, or the separation of the Ultima Thule cultural and civilizational space which includes Ukraine along with all other non-EU countries, or conceptually poorly thought-out ideas of immediate neighbourhood, or the creation of new "financially limited" neighbourhood policies, which are effective neither conceptually nor strategically, and already require substantial modification or, in the best case scenario, the development of some aspects of the new Eastern EU policy all of the mentioned above directly concerns Ukraine. This is highlighted in more detail in the second and fifth sections of the study.

${ }^{414}$ Kolankiewicz, George. Consensus and Competition in the Eastern Enlargement of the European Union // International Affairs - 70. - 1994. - 477 - 495 pp.; Mayhew, Alan. Recreating Europe. The European Union's Policy towards Central and Eastern Europe, Cambridge: Cambridge University Press, 1998; Moravcsik A. Explaining International Human Rights Regimes: Liberal Theory and Western Europe, in: European Journal of International Relations. - 1. - 1995. - 157-189 pp.; Moravcsik A. The Choice for Europe. Social Purpose and State Power from Messina to Maastricht, London: UCL Press, 1998. - 514 pp.; Moravcsik A. What Lessons to learn from Europe's Crises? Is there really a crisis of European leadership? Issue 11, 2004; Sedelmeier U. and Helen Wallace (2000): Eastern Enlargement: Strategy or Second Thoughts?, in Wallace and Wallace (eds.) (2000): Policy-Making in the European Union, $4^{\text {th }}$ edition (Oxford University Press), pp. 427-460.

${ }^{415}$ Baldwin, Richard E., Francois, Joseph F., Portes, Richard. The Costs and Benefits of Eastern Enlargement: the Impact on the EU and Central Europe // Economic Policy. - 24. 1997. - 125-176 p. 
It will be possible to manage the situation only when we are able to anticipate the actions of the EU at least two steps ahead or at least understand the importance of adapting the countries of the new Central Europe and apply these lessons of European integration for our country.

Undoubtedly, the key constant of a truly effective EU strategy, both at the time of its founding and today, remains the successful, optimal combination of political progress with economic and social progress in the context of taking into account the objective realities of the EU's historical development. In the end, this can be clearly seen both at the first stage (first of all, the dominance of the economic component) of European integration and during the establishment of its organic political component, namely the signing of the Single European Act in 1986, the Maastricht Treaty in 1992 and the Treaty of Amsterdam in 1997.

Virtually, both in the twentieth century and today, in the beginning of the twenty-first century, the key issues of theoretical and methodological generalizations, including this scientific research, lie in the role and importance of the nation-state in shaping the theoretical foundations of the European integration process. The wide range of theoretical models of integration - first of all, their evolution in the contradictory process of practice of international relations, led to the development of multi-concept integration approaches to European issues. The role and importance of the nation-state in the integration union, in this case within the European Union, still remains the key issue.

Thus, as centuries ago, the key question is the traditional dilemma of defining the phenomenon of the nation-state. According to the definition of the well-known French philosopher and sociologist Raymond Aron, "international relations are relations between political entities, the latter concept covering the Greek city-states, the Roman and Egyptian empires, as well as European monarchies, bourgeois republics and people's democracies ${ }^{416}$. As Raymond Aaron rightly points out, international relations are political relations, interrelations between states. However, at the end of the XX century, regional unions or economic unions, which by the way are also created by states, as well as by non-state structures, civic movements and initiatives, more and more often are considered to be the subjects of international relation.

The fact is that the main tendency of the current stage of international relation hasn't been changed since the ancient times, as national interests remain a constant motive of international politics, and the essence of international politics is the struggle for power, the state remains the main

${ }^{416}$ Реймон Арон. Мир і війна між націями. Київ: Юніверс, 2000. - С. 32-33. 
international actor that determines the nature of international relations. The power and balance of powers remains as the main control component, and only the behaviour of states and the international unions, associations and institutions they have created, which, according to representatives of "political realism", determines the international system and its structures.

However, denying the glorification of the state and its role in international relations, representatives of "political idealism" consider it false to restrict the study of the system of international relations exclusively to interstate relations, since non-state structures, civic movements and initiatives along with states play an increasingly important role in international relations, which is a manifestation of the democratization of current international relations. It is also necessary to separate the general characteristic of international relations as interstate relations from the characteristic of the kinds of international relations where political relations are a subsystem of interstates relations.

Thus, methodologically, in the course of the scientific analysis of the European integration of the countries of Central Europe, in our opinion, it is necessary to proceed from the following position - political relations form the most important subsystem of the system of international relations with its own structure, functions, process of development. One of the main functions of this subsystem is the synthesis, determination and reflection of all other types of relations that act as independent subsystems in the system of international relations.

The history of problematic issues in the theory of European integration is presented by thorough developments of representatives of federalism (neofederalism) (A. Etzioni, G. Pinder), functionalism (D. Mitrani), neofunctionalism (E. Haas, J. Nye, R. Keohane, L. Lindbergh, P. Schmitter), and its alternative presentations as intergovernmentalism (S. Hoffman) and modern theories of integration - such as, among others, institutionalism (P. Pearson, K. Armstrong, S. Ballmer). Separately should be noted Karl Deutsch's theory of communication and one of the most popular today Andrew Moravchik's theory of liberal intergovernmental approach.

The purpose of this study is not to provide a detailed analysis of each of these integration theories or integration approaches, but it is indisputable to note precisely the basic principles or ideas of the theoretical foundations of the European integration process, which in one way or another explain the realities of the modern European integration process in Central European countries.

Essentially, lengthy theoretical discussions on conceptual problems of European integration have evolved from two opposite approaches - first, but to a lesser extent, is federalism, which can be considered more as a theoretical approach than a theory, and, to a greater extent, functionalism 
(neo-functionalism) and the theory of intergovernmentalism (intergovernmentalism) and their further modifications to the realities of today. These discussions were centred around a wide range of problematic issues that envisaged forms and mechanisms of limiting, or conversely, strengthening national sovereignty in the integration process.

In this context, we will try to trace in detail the essence of these two opposing theories, but not so much their evolution on a purely chronological principle, but from the point of view of distinguishing conceptually formed ideas, which in our time are not only relevant, but also contribute to the critical understanding of modern European integration processes, including Central European countries. Particular attention in the analysis of theoretical generalizations will focus mainly on controversial and not yet soled problems of the modern theory of integration.

In his thorough study "International Theory and European Integration" Charles Pentland, one of the leading researchers in the theory of integration, now a professor at the University of Queens (Canada), points out that the federalists saw the ultimate goal of integration in the creation of a supranational state according to the principles of centralization and transfer of political authority to the highest level. At the same time, the scientist distinguishes two features of the federalist approach - sociological, which determines social activity of people, and constitutional, more precisely the establishment of a constitutional "project", to soften the centralized actions of the state and notes that it was from them that the development of a number of areas in integration began ${ }^{417}$. By the way, during scientific internship of the author of the monograph at the University of Queens (Canada), prof. C. Petland was a research supervisor on the topic of European integration studies; the consultations with this scientist contributed to a more thorough study of integration processes not only on the European continent but in America as well.

The relevance and importance of the theory of functionalism is also determined by the fact that, in this sense, the focus was not on form (the search for a federation or confederation, etc.), but on functions, even of a rather specific nature, which should perform the international community. So, today, neo-functionalism has become one of the leading theories of European integration.

In denying the idea of creating a federation and managing continental scale, David Mitranni, the founder of the idea of functionalism, not only reasonably and pragmatically proved the inappropriateness of creating a

${ }^{417}$ Pentland C. International Theory and European Integration. - London: Faber and Faber, 1973. - P.146-150. 
static and artificial, more territorially limiting federal association, defining it as "misleading federalization". from today's perspective he formulated and substantiated ideas that are already realities today - namely, the role and importance of creating new subjects of international relations - international organizations, moreover, the form Reference network in the context of the dynamic transformation of international relations. According to Mitran, his denial of the territorial limitations of the ideas and possible practices of the pan-European federation concerned, in particular, the consideration of the geopolitical realities under which these ideas were formed, that is, when Europe essentially controlled a large part of the world through its metropolises.

In view of the current large-scale 2004-2007 and future EU enlargements, it is very interesting that D. Mitrani's theoretical generalization of the clear separation of the dichotomy of the concept of continental unions (where priority is given to the definition of territory between union members and foreigners) and the concept of a world, universal league as defining functions to integrate with as many interests of their participants as possible). In this connection, two Mitranni theses are of key importance. First, regional integration projects will play territorial quasistate functions, but already at the supranational level, where only the most powerful states will play a decisive role. However, it should be noted that Mitrani notes the undeniable fact of the successful implementation of functional logic practices in the creation of specialized European institutions - the European Coal and Steel Community and the Euratom.

And secondly, what directly touches the present, as the gradual strengthening of the distributive function of the new European border between the EU and Ukraine, namely the denial by David Mitrani of the use of territorial logic - as the establishment of real borders for political purposes and the definition of restrictions on membership in the region integration associations.

In other words, an unbiased and critical approach in general to the theory of European integration and, in particular, to David Mitranni's creative work, allowed Ben Rosamond (we consider his work "Theory of European Integration" (2000) - one of the contemporary deep theoretical analytical developments of the following issues) conclusion about the value of the theory of functionalism. It should be noted that even Mitranni himself did not claim to define his ideas as a coherent theory. "The historical significance of functionalism lies in the fact that it laid the foundations for a non-functionalist theory of integration, the field of international relations theory most associated with the development of the European Communities," Ben Rosamond notes. 
Many non-functionalists recognize Mithran as their intellectual father. Indeed, the emphasis on technocratic needs as the basis for deeper and longer-lasting peacekeeping systems coupled with evolutionary logic, which implies a spillover effect (more precisely the idea of a so-called "spillover" process of regional change, such as deepening integration across segments or segments current system) indicates their close relations.

Of interest are the theoretical generalizations of representatives of neofunctionalism, first of all, Ernst Haas, who not only highlighted the key role of the political factor in the integration process, in particular as the creation of post-national political communities, the gradual integration in the spheres of "low" and "high politics". a quality process that cannot be equated with intergovernmental or intergovernmental cooperation. An integral part of the theory of neo-functionalism is the idea of "overflow", but already significantly modified to the problems of the realities of the European integration process. Exploring the processes of European integration through the prism of the principle of supranationality in the economic dimension - as an evolution from a free trade area, a customs union to a common market, economic and monetary union, ak noles voles also requires reforms of institutional foundations, as well as a qualitative change in political integration, considered the nationality and political nature of the integration process.

Neo-functionalism (at least in its early manifestations) was an attempt to make sense of it, providing a theoretical basis for the political strategies of the founders of post-war European unity. Such personalities as Jean Monnet and Robert Schuman imagined quite clear the way for an integrated Europe. Their pragmatic approach directly denied the idealism of the federal movement. The Federalists lost their basic arguments regarding the direction of European postwar unity as early as the early 1950s.Although the federal system of Europe was still regarded as the ultimate goal of the integration process, it became apparent that it could not be achieved as a practical goal through certain rational proofs and far-sighted constitutional projects, but only through economic growth and the development of a common development strategy. This approach has been identified as a technocratic and functionalist first and foremost by Ernst Haas.

Of course, the architects of post-war integration had the ultimate goal of achieving political unity between the states of Europe in the context of the settlement of Franco-German relations, and saw political unity in the presence of the creation and operation of supranational institutions as a consequence of economic interaction and interdependence of states.

It is in the context of a thorough analysis of existing conceptual and theoretical approaches that Ben Rosamond characterizes (outlining seven 
explanatory proposals) the strategy that formed the basis for the creation of the European Communities:

1-Moderate integration, first and foremost in "low policy" areas, but under the condition that they will represent key sectors of the economy (eg coal and steel).

2-Creation of a supreme Community body, not burdened with heavy baggage of conflicting national interests, with the power to monitor the integration process and to enable it to act as an organizer of further integration.

3-The integration of certain sectors of the economy across national borders creates a functional pressure for the integration of related sectors of the economy. This impetus must continue, especially in the context of a leading role assumed by a higher authority of the Communities. The consequence of these processes is the gradual and progressive intertwining, increasing interaction and interdependence of national economies.

4-Deeper integration will not only be organized and channeled by a higher EU body, but gradually social interests will be channeled from national forms of government to European supranational structures as a more effective way of satisfying those interests.

5-The deepening of economic integration will necessitate further institutionalization at the European level, since wider integration requires more complex governance.

6-In other words, political integration is an inevitable by-product of economic integration.

7-Accordingly, the gradual economic integration, accompanied by a degree of supranational institutionalization, is an effective way of creating a long-term peace system in Europe.

For Haas, the Monet method was rooted in an analysis of the convergence of the preferences and pragmatic self-interests of political actors and subjects of international relations in Europe. In this context, it should be noted that these ideas did not in any way confirm the basic provisions of "political realism" or even neo-realism. So, a kind of implantation ideas of modern political realism, above all, a clear definition of the eternal role of the state as the main actor of international relations can be considered an intergovernmental approach or theory intergovernmentalism. Stanley Hoffman formulated the basic principles of this European integration theory, where states within the framework of integration unification have a substantial advantage over institutions of integration creation.

In essence, Hoffman argued that the logic of Monet-Haas only works in the field of economic integration in the context of the interests of actors, and in political integration, the priority of the ideological and pragmatic interests 
of political elites determines the progress of the integration process, in particular, in the sphere of «low politics», to integration and cooperation, while in the field of "high politics" - to surrender their sovereignty is very problematic for the states.

The representative of liberal intergovernmentalism, Andrew Moravchyk, defining the process of European integration as a "two-tier game" - the formation, presentation of interests at the national level as "demand" and strategic negotiations between the states, is defending their "proposals" at the international level, emphasizing the viability, draws on the example of the Single European Act to analyze and conclude on the political and economic convergence of three powerful and influential EU Member States - namely Germany, France and Great Britain. Moreover, in this case the researcher considers realization of the interests of these states as a key factor of integration.

E. Moravchyk expressed a very interesting opinion regarding the current considerations regarding the so-called "crisis of leadership" in the EU. Refuting the myths about the crisis that he thinks are triggered by the myths of the lack of a charismatic European integration leader today and the myths of the so-called bicycle theory (according to which if the integration is suspended, then the consequences will be relevant), Moravchyk claims that it is today that a functional degree of political maturity has been reached within the EU, and the EU has "ridden" a three-wheeled bicycle by drafting the Constitution. So, according to the scientist, the European Union will never fall, even if it stops, and its institutions and especially its leaders simply lack the "main project" around which should be united for the sake of further integration: "And now, after half a century of success "Europe has reached a one-year limit, is entering a period of declining profits, and is developing more constructively, although further economic expansion is not beneficial."

It is clear that the problems related to the formation or actual definition of the theoretical foundations of the modern complex European integration process are objective, which is connected with the deepening and enlargement of the EU in the context of changing theoretical approaches of political realism (neorealism) and political idealism.

The theoretical understanding of the contemporary phenomenon of European integration is considered appropriate in the future through the prism of EU formation - as a real actor of international relations, which ultimately clearly defines the global strengthening of the geopolitical positions of a united Europe as a result of the fundamental and formal reforms. the latest EU enlargement inclusive. Although, the more practical nature of the theoretical provisions of today's complex European integration process, which includes a complex of political, economic and institutional factors of modern European integration processes, is being pursued today. 
A qualitative new level of the European integration process in the context of radical geopolitical changes on the continent, marked out the tendency to search for theoretical models or modern modification of traditional theories of integration and theories of international relations to explain contemporary European integration processes.

The complexity of the situation arising from the expansion of the sphere of influence of its interests on the part of the EU in the context of the establishment of the European balance of powers, the balance of interests is also determined by the fact that absorbing, more precisely "mastering" a new geopolitical space, the EU has come closer to excellent (again, the "other", it is not clear as to the nature of the EU) geopolitical space of Eastern Europe, with subjects which nolens volens he is forced to interact, but still is not carried out effectively. In this context, the search for EU enlargement theory is not something that does not answer the truth, but does not even have time to find out post factum - what is actually accomplished and how it will affect tomorrow.

And it is in this context from the point of view of the formation of theoretical and methodological foundations of scientific research that two very important problematic questions arise. First, it is the separation of theoretical and methodological foundations of the formation and modern development of the region of Central Europe. Secondly, it is a conceptual definition of the role and functions of the new eastern border of Central Europe and the European Union.

Reflections and discourses on whether or not Central Europe exists, whether it is myth or reality, have become relics of history today. The urgent question of today is the dynamic development of a new format of relations between Ukraine and the neighboring countries of the "first order" by the states of Central Europe (full members of the European Union) in the context of a truly functioning single European integration space, which has come close to the borders of Ukraine.

Given the dynamic evolution of the EU's qualitative characteristics, it is desirable to apply a comprehensive approach to the study of the European integration process, a multi-causal, multilinear approach, to find out a network of interrelated causes of historical changes that, from the perspective of the research methodology, makes it possible to understand the European integration as a whole process which has internal logic of development, with specifying the dynamics of change of its qualitative characteristics.

It is essential to analyze, first of all, the theory of European integration, its key provisions, which are still under discussion today, and which are used to varying degrees to explain some of the complex phenomena of today first of all, international relations in Europe, in the world, as well as development of European integration. Moreover, only by highlighting the 
problematic issues of a complex multifaceted mosaic of European integration theory that require comprehensive research - can we formulate conceptual generalizations of certain specific segments of the EU's eastern enlargement - in particular, EU-Ukraine relations, Eastern EU enlargement, and European Eastern issues.

The fact is that today there are many theoretical generalizations about the process of development of integration of sovereign states of the European Community, further - the European Union, as well as scientific explorations on the evolution of theoretical foundations of the European integration process. Moreover, with a significant radical change in the geopolitical situation on the European continent at the turn of the XX-XXI centuries, as well as due to the gradual dynamic formation (note that this process is happening right now) of a new subject of international relations in the global dimension - the European Union, at the beginning of the XXI century, scientists are trying to generalize theoretical models of integration, or at best to develop a new model ${ }^{244}$. However, it is clear that this is a very difficult task, since the development of a new theory of European integration not only requires a comprehensive approach in the methodological sense, but also takes into account the factors of economic, institutional and political nature of the objective dynamic internal development of the EU, along with the analysis of the effect of factors of direct external character, which are also changing dynamically in the system of international relations.

The issue of identity, the formation of political culture is crucial for the development of civil society. Culture and nature are essentially two parameters of the space within which any nation emerges and develops. The question is how these two parameters interact and how they affect the specificity and fate of the culture that exists within a particular space in the context of interaction with the environment, in the process of "reproduction" of uniqueness in the context of that interaction. Culture emerges and develops in a specific geographical space, the specificity of which is significantly reflected in the characteristics, forms of the culture itself, and understanding the characteristics of geographical space helps to see the historical geocultural issues of Central Europe in its diversity.

By distinguishing the specific geographical and therefore geopolitical space expanded to the East of the EU, its specificity, which depends on the specificity of the objects located within this unique space of Central Europe, we consider it appropriate to determine that, like any other space, which is considered not abstractly, but from a substantive-substantive point of view, is internally hierarchical and limited, and also assumes the presence of its own "center", a kind of "reference point", in relation to which the "coordinates" of objects in this space. From the point of view of exploring the geopolitical situation in the Central European region, it is especially 
important to analyze the so-called metacultural systems, in this case, as the West and the East.

Based on the fundamental axiom that Europe is in fact a set of values, values that are inherent in society, and taken for granted, it should be noted that in the new geopolitical conditions of Central Europe and Eastern Europe, their borders, frontiers, the so-called cultural maps of a certain space take on an unmatched importance. In this case, it is not just a process of establishing a new eastern border of the EU, and then its transfer or possible destruction. No. This is a much more complicated process. These are the conditions of its occurrence, the space in which it has existed and will exist for a long time. However, we do not absolutize the border as a thing that lives on its own by its own rules and laws.

It is important to emphasize that there is a connection between the specificity of the historical-geographical and geopolitical space within which a certain society is formed and developed, and its culture, cultural space - because the geographically defined territory of the society is located not in a vacuum, surrounded by other cultures. In this context, from a theoretical and methodological point of view, we can distinguish such an important phenomenon as civilization - as a "unit of measure" of historical existence, a society of longer length, both in space and in time than national states, or states united in any other political unions, as noted by the famous scientist Arnold Joseph Toynbee ${ }^{245}$.

According to Toynbee, the formation of a particular type of civilization requires interests to be integrated into the system. The integration of qualitative changes in economic, socio-cultural, technological and other spheres of development ultimately creates the conditions for "selection" from the system of interests of a set of civilizational values (landmarks), which are gradually consolidated in the "genetic code" of society. Such a process is indicative of the appearance, in fact, of a type of civilization associated with the transition of first-class local civilization communities to higher-order communities. Thus, the dynamics of human history can be seen: firstly, as the emergence of types of civilizations; secondly, as the increase in number of local and civilizational communities within them; thirdly, as the evolution of types of civilizations and their corresponding communities, both at the expense of their own sources of development, and as a result of the interchange of information, material, cultural and other values; fourthly, as the extinction of first-class local civilizational communities.

The isolation of environmental issues in the Toynbee concept is one of the most important ideas in the context of the idea of the development of society - as a whole system - as a process of interaction, mutual influences of internal and external factors, or, in other words, as a process of system development in the context of being actively influenced by its environment. 
Based on Toynbee's conceptual propositions, let us identify two important methods of his research which, in our view, contribute to a more adequate and comprehensive analysis of the EU's new eastern border.

Firstly, it is the application of an extremely important principle in exploring the EU's new geographical space - as a geopolitical and geocultural space, namely the principle of alternative. One of the main ideas of the concept of Arnold Joseph Toynbee (which, in essence, distinguishes not only the concept of civilization from other debatable definitions, such as Oswald Spengler, but above all clarifies the very essence of the concept of civilization) is, in our opinion, the so-called "overcoming" fatalism. According to Toynbee, the evils and subsequent destruction of civilization in history were not fatal, because they are the result of human error, the consequence of the inability of a community to find an adequate Answer to the Challenge ${ }^{246}$. According to Toynbee, there is always an opportunity to avoid falling into the abyss. It all depends on the living pulsating nucleus of history - on man, on whether he has the spiritual strength to resist world entropy.

Secondly, logically speaking based on the principle of alternative development of history, Toynbee rightly argues that the dynamics of life is not reduced to linear processes, but in reality is the result of complex interpenetration of phenomena. It is only with such awareness that one can understand that in society any process carries with it hidden nonlinear, probably important parameters.

Among the basic principles of the theory of civilizations of the English historian Arnold Toynbee, it is worth noting also the essence of the theory, which is cyclical in the sense that it does not view history as a linear progressive movement towards a single purpose in which all peoples go in the same direction, overtaking or falling behind one from another.

The role and place of the new Central Europe, now formed with clearly defined eastern borders for the long term in a new geopolitical configuration on the continent, is beyond doubt. As a real historical region or geopolitical region, Central Europe exists, but it is difficult to delineate it, because it is not a geographical concept with clearly defined borders, but in the historical and cultural sense the borders are even wider. In this paper, the countries of Central Europe are - the Republic of Poland, the Republic of Hungary, the Czech Republic and the Slovak Republic. However, over the decades, two conceptual generalizations have clearly emerged (it is clear that there are too many ideologues or political claims). The first one is aimed at domination, the second one is aimed at protection. Mittelevrop's concept was, in fact, a reflection of the German-Russian struggle for the region, regarded as a strategic foothold for conquest. After the Second World War, this region fell under the Soviet Union's influence with the imposition of a corresponding ideology, so the efforts of the countries of the Central European region were 
initially directed against the Soviet regime in 1956 in Poland and Hungary, in 1968 in Czechoslovakia and of course since 1989, with favorable foreign policy circumstances - Central European countries have clearly defined their strategic goal - the fastest possible Euro-Atlantic integration.

Due to the geopolitical segmentation of Central and Eastern Europe, at the end of the XX and the beginning of the XXI centuries, the process of forming a new Central Europe was completed, more specifically, a renewed Central Europe, which "return" process to Europe, has only just begun.

Comprehensive scientific analysis of the powerful collection of works of scientists, researchers, as well as writers, cultural figures, statesmen of the XIX-XXI centuries allows to state with certainty the following generalizations regarding the methodology of the study:

Firstly, it is not possible to seriously explore the modern theme, the idea of Central Europe, without a thorough study of the history of the peoples of Europe, Central Europe.

Secondly, the self-identification of Central Europe took place in a complex positioning within - European - non-European, which essentially expresses belonging or a direct demonstration of alienation from a certain geocultural, civilizational space, so the study of the so-called Central European identity is an important issue.

Thirdly, at the heart of the content of the historical, cultural, geographical, geopolitical space of Central Europe - as the definition of the problem of research, lies the world-wide category - civilization.

The real events of the beginning of the third millennium de facto and de jure testify to the formation of new dividing lines in Europe that clearly distinguish the omne quod est igitur nulla regione viarum finitum est for a rather long time period, namely the eastern border of Central Europe, as in the spatial and psychological dimensions, also in the cultural and civilizational dimensions. It is clear that the cultural and civilization maps of Europe do not coincide with the geostrategic dimension of Central Europe's spatial limitations as of 1 May 2004. However, since the 1980s there has been a clear fragmentation of the more or less unified regional space of Central and Eastern Europe. As a consequence of this fragmentation, there is a clear separation of the Central European segment, which has unmatched geopolitical and geostrategic implications, including for Ukraine.

When everyday life radiated in a culture of behavior, a culture of work, a culture of language, of representatives of a certain society, such as conformity to European identity, becomes their immanent essence, the problems of conformity with Copenhagen or any other criteria will become relics of history. According to the logic of gradual development, the latest but not the last enlargement of the European Union to the East at the beginning of the XXI century causes profound changes in the geopolitical situation in Europe, defines a clear geopolitical demarcation on the European 
continent, including the Eastern "newer" Union. Among the new members of the EU, four Central European countries are singled out - Poland, the Czech Republic, Slovakia and Hungary, whose accession on May 1, 2004 to the European Union both in spatial and temporal dimensions has a direct impact on the formation of a new qualitative system of relations in the field of enlargement between European Union and Ukraine. However, the central position and powerful influence of these Central European states as creators of the new EU Eastern policy still requires some time and a strong control policy within the EU.

The geopolitical segmentation of the Central and Eastern Europe regions has a direct impact on Ukraine in the new distribution of forces on the continent, since de facto and de jure in 2004 ended long (though historically it is a small amount of time) and important (but not final) stage of systemic transformation of the countries of Central and Eastern Europe.

Thus the geopolitical segmentation of Central and Eastern Europe, at the end of the XX and the beginning of the XXI centuries, the process of forming a new Central Europe was completed, more specifically, a renewed Central Europe, which "return" process to Europe has only just begun. Therefore, in a theoretical and methodological dimension, the following conceptual conclusion can be formulated.

In our opinion, the formation of a new Central Europe at the turn of the century is a multidimensional process, functioning according to the internal logic of development - as the development of a holistic organism in constant interaction with the new geopolitical and geo-economic space of the EU, which will continuously "synchronize" its interests and indisputably "answers" with the status and response of their newest elements - Central European countries.

Europe, Middle Europe (Mitteleuropa), or as Central Europe (Zentraleuropa, Central Europa), Eastern Europe - these are attempts to divide the western part of the Eurasian continent in theory and in practice continue today. It would seem that strengthening the European integration process, expanding the idea of Europe, Europeanness in the civilizational dimension will contribute to a more active spread of European values, European culture, greater openness and interpenetration of cultures. However, the dynamic unification of sovereign states in the west of the continent in the format of European integration, nolens voles makes it increasingly clear that they are separated from each other both in theory and in practice - the so-called Europeanness from non-Europeanness in the wider context of civilization. First of all, the mental image of Europe, Central Europe in consciousness, the problematic issues of European identity define a very complex, multidimensional, contradictory paradigm of the concept of Europe, in particular Central Europe. 
It is not only about the definition and spatial-geographical, but also about the geostrategic definition of Central Europe. It is important to emphasize the fact that the spatial configuration of Central Europe is interpreted differently by historians, politicians, geographers or political scientists, moreover, when one analyzes the research from the point of view of the researcher's belonging to a particular region, that is, depending on his country of origin, the mosaic of views is further expanded.

Traditionally, the concept of Europe, Central Europe is associated with the issues of acquisition or conformity of European identity, the presence of this mental image in the collective consciousness, the historical memory of a particular people. This issue has not lost its relevance today, and it is enough to analyze Eurobarometer data, sociological surveys of "old" Europeans and a certain thing of "neophytes". And more clearly, the latest European Union documents show the recent differences in the desire for a clear division in the "other for Europe" plane, where EU tries to shape its "new, oriental" philosophy, whether it is policy, but to no avail. Unfortunately, the systemic idea is, like, what to do with our new eastern neighbors? - now the EU is missing.

Today, for many, the concept of Europe also serves as a certain ideologue. According to others, it is only a mythology that exists only in theory. Certainly, only those who have not studied the history of the socalled "small" (Masaryk) peoples of Europe, who are accustomed to imaging non-alternative ideologues in the right direction, or who have not been able to grasp the significance of the central European cultural heritage.

One of the most pressing issues that is being discussed not only by political scientists and historians is the question of Central Europe, which is also a testament to the need for a thorough coverage of the problem in science. In particular, it is legitimate and historically conditioned to use the current concept of Mitteleuropa. Although this is a fundamental question, there is no unanimous view, despite its broad historiography, which in turn testifies to the revival of interest in this subject. The fact that discourses today are about the validity of the existence of an imaginary or real prospect of Mitteleuropa's revival testifies to the importance of both developing a new theoretical and methodological concept and defining the components of modern Central Europe.

The concept of Mitteleuropa "Central or Middle Europe" emerged during the First World War, although the roots of this category can be found in the early nineteenth century. Thus, for the first time, a more or less clear definition was formulated by economist Friedrich Liszt, who noted that Germany, which did not exist at the time, does not have to look for colonies or zones of influence, but in naturally accessible territories from the Danube, 
east to the Black Sea. Other German publicists and scholars, such as G. Daniel, K. Frantz, and F. Ratzel ${ }^{418}$, have taken this view. The conceptual justification for the Mitteleuropa category was already received in the work of Lutheran priest Friedrich Naumann in 1915 during the First World War, and it is not a coincidence.The hope of victory in the war between Germany and its adherents also determined the need to develop a clear plan for what Mittele economics should look like and a military and economic alliance in the German-speaking territories and Austria-Hungary together with the Polish, Baltic and southeastern territories. A number of Central and Eastern European Central and Eastern European states, together with Germany, were regarded as Central Europe (Mitteleuropa) or Central Europe (Zentraleuropa), in fact, as the area of domination of the future Greater Germany. However, the Monarchy collapsed, Germany lost the war, so the implementation of the Pan-German idea of "Central Europe" was for some time "forgotten".

Although it is undoubted that, in theory, among the many ideas of consolidation of the peoples of Central Europe, two brilliant and logically formed concepts deserve special attention - as geopolitical alternatives for the formation of Central Europe, which have unfortunately not been realized. First of all, we consider the conceptual ideas of the Danube Confederation of Peoples of Europe, the Central European idea expressed by Yasi Oscar in the framework of the Conference of European Federations ${ }^{419}$, as well as the "New European" idea formed by Tomas Masaryk which state that the federations of small nations and the master-states of Europe are the conceptual idea of T. Masaric's, which existed in such a creation as the "Small peoples' nations" between Germany and Russia ${ }^{9}$. However, based on an objective analysis of the international situation of the "small states" of Europe and the positions of the great powers regarding the post-war ordering of Europe, it should be noted that these ideas of consolidation of the small peoples of Central Europe were not realized.

Strategic direction of development of geopolitics of the states of Central Europe during the XX century. was caused by the presence of major world powers, empires whose struggle for a leading role, spheres of influence in the world systematically determined the geopolitical reorientation of the countries of the Central European region. Historical experience of the twentieth century shows that the possibilities of independent development of

${ }^{247}$ Geopolitikai szöveggyűjtemény. Budapest, 2002. - 210-234.old.

248 Jászi Oszkár. A Monarhia jövője. A dualizmus bukása és a dunai egyesült államok. Bp.: Új Magyarország, 1918. - 41-72.old.

${ }^{249}$ Masaryk. T.G. Nová Evropa. Stanovisko slovanské. - Pr.: Nakladem Gustava Dubského, 1920. - S. 58,185-190; Чапек Карел. Бесіди з Т.Г. Масариком - Львів: Каменяр, 2001.C. $38-55$. 
the states of the region were too limited, moreover, during and after the two world wars, the countries of Central Europe systematically lost their main general civilizational landmarks.

Again, during the 1920s and 1990s, the peoples of Central Europe were given the chance to lose their meta-orientation and to clearly define their place and role in Europe and in the world. Of course, the new geopolitical realities require the development of theoretical and methodological conclusions, the development of a new system of the category "Central Europe". As it is absolutely not possible to use the ex post Mitteleuropa category today, even modern studies about this category indicate that there is no consensus among scientists on this issue, especially regarding its spatial configuration. However, again referring to the definitive definitions of Milan Kundera, let us note that the essence of European identity, for the Hungarian, Czech, Polish means not a geographical phenomenon, but a spiritual concept, synonymous with the word "West". As for over a thousand years their states have been part of Europe whose roots date back to Roman Christianity.

However, still today it is possible to note a number of troubled issues that Central European countries have to decide as de jure full members, but before, the so-called "transitional conditions" or "transitional periods" must be de facto determined by them:

- clearly defined quotas and temporary employment restrictions for Central European neophytes;

- defined time lag in the introduction of social guarantees and wages for new Europeans;

- the need for lobbying in the redistribution of funds from the Structural Funds; everyday "fight" with elders on "poverty" and active lobbyists led by Spain;

- the struggle for preferences in the common agricultural policy;

- the desire to participate on an equal footing with the EU "elders" in the formulation of real policy (note that the real involvement of Central European countries in the creation of an effective and prudent EU Eastern policy would be the best event for Ukraine).

All this is happening nowadays with the hard work of the newest Europeans in order to achieve a high socioeconomic level or at least reaching it by all major macroeconomic indicators. It is extremely important in this sense to understand the fact that the real European integration of the peoples of Central Europe is just going to start, but with new opportunities. This category perfectly describes the new possibilities and their use for the modern of European integration.

In our view, attempts of scientific analysis of the concept of Central Europe (as a component of the concept of Europe) is a very important and relevant scientific task, as geopolitical segmentation of the European 
continent is now taking place. The consequences of which increasingly place on the agenda the question of conformity to European and civilization choice. This process of formation of a new Central Europe is of paramount importance both in terms of changing the overall geopolitical situation in Europe, as well as in terms of the breakup of the region into Central Europe and Eastern Europe and, accordingly, the formation of a new format of relations within the EU (Central Europe - Ukraine).

Conceptual synthesis of the process of European integration of the countries of Central Europe is possible to be distinguished in three segments:

1. first, it is the understanding of the modern processes of European integration of the states of Central Europe as the "return" of the countries of the region to Europe,

2. second, this process is an extension of the European Union's area of interest to the east,

3. third, due to the current processes of deepening and enlarging the EU, as well as strengthening the geopolitical role and position of the European Union.

The process of so-called "return", "accession", "entry" of Central European states into a single geopolitical pan-European space (or vice versa - the absorption of this Central European space by the European Union) is a much more complicated process, more time-consuming in space and time than it seems, much more complicated than meeting the Copenhagen criteria, and then other always-relevant criteria.

In fact, the two-pronged processes have now taken place in the western part of the European continent: segmentation of Central Europe and Eastern Europe as well as

transformation of the geographic and geopolitical, historical image of Central Europe - the neighbors of the first order of Ukraine.

Today and for some following years, the EU is forming a new system of relations - as the status quo with Ukraine, because the geopolitical situation with the accession to the EU of the states of Central Europe has also changed for both de facto and de jure. And for Ukraine as a subject of international relations, it is of its highest importance first of all an internal need - which must become an immanent essence of our country regarding the need for civilized development of society, development of democracy, formation of the "middle class" and market economy - not in order to meet European standards, but in order to truly become an actor in international arena, under the qualitatively new geopolitical circumstances on the European continent.

The consequences of the EU enlargement process for Ukraine are determined not only by the current relations with the Central European countries on border management, visa application or changes in the trade and economic sphere, but above all, the consequences are caused by internal structural, institutional changes within the EU, including the recent Eastern 
policy. Indeed, current European Commission searches for new strategies and mechanisms for reciprocity in the implementation of "new or immediate neighborhood" ideas in the EU-Ukraine plane (since it is difficult to call it a concept) do not correspond to the rapidly changing realities.Although this can be understood as a methodological point of view, these ideas are also socalled one-sided - on the part of the EU, as a defense of a rather wide range of interests, where priority is given to the economic security and immediate security of their new eastern borders. It should be noted that the issues of developing inter-regional, cross-border cooperation or defining a new format of relations with Ukraine have only declarative intentions regarding the importance and necessity of cooperation with Ukraine together with other new neighbors.

Without any doubts, the absence of a truly new format of bilateral relations, of conceptually weighted science-based cooperation strategies and mechanisms of interaction between the subjects of international relations between the EU and Ukraine makes it impossible as today to be a clear perspective.

In our view, a deep rethinking of the geopolitical role and importance of this small but extremely important geopolitical region in the center of Europe, in the context of maximally taking into account the totality of realities and factors, moreover in the context of isolation of alternatives to the historical contradictory nature of the Center an opportunity to formulate new approaches to the study of Central Europe in the context of deepening and expanding the European integration process.

In the third millennium, in the consequence of the deepening and enlargement of the European Union, on May 1, 2004, geopolitical segmentation of the Central and Eastern Europe (CEE) region took place. Its break up into separate segments of Central Europe and Eastern Europe as in geographically, socio-economic and political dimensions. It is clear that, in our view, the new Central European border, which is emerging and does not coincide with the cultural borders of Europe, is not only a simple linear space or a spatial barrier, which, by the way, clearly delineates in this case the region of Central Europe and Ukraine.

In fact, on May 1, 2004, a clear structuring of the geopolitical space of Central Europe and Eastern Europe took place in the Central European region. It may be more correct to formulate these events as a natural and natural process of "returning" the countries of the region to Europe, as the disappearance of distribution lines in Europe. However, rather problematic issues of concern, the realities of today require a deeper, comprehensive study (territorial, socio-economic, ethno-cultural, geopolitical components) of the modern European integration process in Central Europe. The study of this problem is of particular urgent importance for Ukraine, since the 
immediate consequences of the EU's enlargement to the East are already available today (mostly of a negative nature).

An important element in the study is the definition of the region of the new Central Europe. It is clear that the rules of the game, which are periodically determined and determined by the major players in the international arena, will change depending on the current state of the future, in the context of the relevant geopolitical situation.

However, it should be emphasized that even if the historicalgeographical or geopolitical space, which is studied in the dynamics of its development, is changeable and may change due to certain historical circumstances, then the geocultural images are formed more long-term and do not disappear. Thus, from a theoretical and methodological point of view, it is important to consider the definition of the geocultural space of Central (Central) Europe as an image that, in essence, also determines the scale of the new Central Europe. However, it should be noted that a large-scale image is Europe, but images or symbols or even mental maps that define the internal parameters of a country determine its identity.

At the beginning of the third millennium, the countries of Central Europe returned to the path of European civilization, though as Milan Kundera brilliantly put it: "Central Europe was eager to be a condensed version of Europe itself in all its cultural diversity - a super-European Europe, a smaller model of a European state that would be made up of a state, created by one rule the greatest variety within the smallest space" ${ }^{, 20}$. Whether this path will be successful from 2004 onwards within the EU, time will tell, but the success of their European consolidation nature will depend on the ability of the Central European states to "overcome" the so-called eternal images, complexes that are still firmly preserved in the historical memory.

Today there is a kind of implantation of the geographical space, the region of Central Europe, into the sphere of the wider cultural, civilizational space of Europe. From 2004 onwards (let's define it as the first stage of Central European states' adaptation to the EU, which can extend for ten years) the peoples of the Central European region, who are not burdened by their identification by the way, have been experiencing daily problems since 2004. After all, in 2004, the integration of Central European countries into the European space has only just begun - and it will require painstaking work and, above all, a change in mentality to the present - as using existing opportunities, actively working towards using these opportunities, rather than waiting for preferences. Therefore, in the first phase, along with the euphoria of prospects for rapid and dynamic, almost "automatic" integration,

\footnotetext{
${ }^{9}$ Jászi Oszkár. A Monarhia jövője. A dualizmus bukása és a dunai egyesült államok. - Bp.: Új Magyarország, 1918. - 41-72.old.
} 
there will be disappointments and a quest to build a truly European identity in everyday life in the context of overcoming the so-called complexes of European inferiority by the peoples of Central Europe.

However, today it is possible to note a number of problematic issues that the Central European countries should address as de jure full members, but so-called "transitional conditions", "transitional periods" will be de facto before them. In particular, these are clearly defined quotas and temporary employment restrictions for CE neophytes today; defined time lag in the introduction of social guarantees and wages for new Europeans; the need for lobbying in the redistribution of funds from the Structural Funds; daily "fight" with elders on "poverty" and active lobbyists led by Spain; the struggle for preferences in the common agricultural policy; the desire to participate on an equal footing with the EU "elders" in the formulation of real policy (note, in this sense, that the real participation of Central European countries in the creation of an effective and prudent EU Eastern policy would be the best event for Ukraine) and all this will take place under the conditions of hard work from new Europeans with a goal to achieve a high socioeconomic level or at least approximating it to all major macroeconomic indicators. It is extremely important in this sense to understand the fact that the real European integration of the peoples of Central Europe is only just beginning, but with new possibilities. It is this category - new opportunities and their use that best explains the essence of the current challenge of European integration ${ }^{421}$.

To paraphrase Fernand Brodel, who quite rightly and logically argued that the world is littered with "periphery", understanding by this expression of the country, zones, belts of underdeveloped economies, clearly defining that the spatial scheme of the world is an assembly, connection of the connected zones, but at different levels, because at least three areas, three categories are defined in space: a narrow center, minor, well-developed regions, and in the end everything is a huge outer neighborhood, peripherals that were everywhere in the world, we can do the following a logical generalization. Today, the EU mutates mutandis will move centers not only to peripheral regions, but also to the center for itself, because the center has several floors, it is shared within itself - and this, in the long run, clearly defines geopolitical changes in Europe, namely the global strengthening of geopolitical the position of a united Europe as a result of the accession of Central European countries to the EU.

The vitality of civilizations, their capacity for high development, depends on their ability to maximize the use and development of their reproductive

\footnotetext{
${ }^{10}$ Masaryk. T.G. Nová Evropa. Stanovisko slovanské. - Pr.: Nakladem Gustava Dubského, 1920. - S. 58,185-190; Чапек Карел. Бесіди з Т.Г. Масариком - Львів: Каменяр, 2001.C. $38-55$.
} 
potential in response to what Arnold Joseph Toynbee called the "challenge of history." Based on this concept, the development of a new region of Central Europe will be the answer of European civilization to the call of the Universe. By the way, the process of "redistribution" of civilizational space within Central and Eastern Europe leads to profound changes in the sociocultural and ethnic structures of Eurasia in general.

The geographical boundaries of civilization may not be in harmony with state-political ones, the presence, absence and configuration of which cannot undo the integrity that has emerged and is realized through the totality of human, political, economic, cultural interconnections and interdependencies. Undoubtedly, the fuzzy contours of civilization are one of its characteristic features.

As rightly pointed out, Fernand Brodel cultural maps do not exactly coincide with economic cards, and this is quite logical. Is it not because culture originates from the endless past: economies have changed one another, political institutions have collapsed, societies have emerged one by one, but civilization has continued on its way. Civilization is the old man, the patriarch of world history ${ }^{422}$. In addition, there was no easily distinguishable cultural boundary that would not be evidence of many completed processes.

The need to understand the consequences of large-scale changes on the European continent at the turn of the century, requires not only the search for new worldviews, values, standards of life and the acquisition of European identity by the peoples of Central Europe and Eastern Europe, but also the study of values, worldview structures more. Of particular importance in this context is geocultural issues, such as the isolation of the specific relationship and interplay between the historical and geographical space and the culture of society of the newly enlarged East of the European Union.

\section{CONCLUSIONS}

In the XX century, one of the most prominent figures of Ukrainian history was undoubtedly Metropolitan of Galicia Andrey Sheptytsky. A prominent religious figure of the time, he played a significant role in the growth of self-awareness of the Ukrainian people. It is difficult to overestimate the contribution of Metropolitan to the education, science, cultural progress of the Ukrainians. Although his activity was spread primarily in the Western Ukraine, but it has resonated enormously with the rest of Ukrainian lands.

${ }^{422}$ Бродель, Фернан. Матеріальна цивілізація, економіка і капіталізм, XV-XVIII ст. У 3-х т. Т.3. Час світу. - Київ: Основи, 1998. - С. 53. 